\title{
PROBLEMATIKA PENERIMAAN PESERTA DIDIK BARU (PPDB) DENGAN SISTEM ZONASI DI SEKOLAH DASAR (SD) KOTA MATARAM
}

\author{
Muammar \\ Pendidikan Guru Madrasah Ibtidaiyah, Universitas Islam Negeri Mataram \\ Email: muammar@uinmataram.ac.id
}

\begin{abstract}
Abstrak: Penelitian ini memaparkan problematika penerimaan peserta didik baru (PPDB) dengan Sistem Zonasi di SD Kota Mataram. Jenis penelitian ini adalah kualitatif. Kehadiran peneliti merupakan instrumen utama atau kunci. Penelitian ini dilakukan di 3 SD Kota Mataram. Data diperoleh dari kepala sekolah, para guru, dan calon wali murid. Data dikumpulkan dengan wawancara mendalam, observasi, dan dokumentasi. Data dianalisis secara deskriptif dengan analisis interaktif, yaitu reduksi data, penyajian data, dan penarikan kesimpulan. Validitas data dengan kriteria dan teknik pemeriksaan, yaitu dengan cara memperpanjang waktu pengamatan dan menguji dengan teknik triangulasi. Hasil penelitian menunjukkan bahwa problematika PPDB dengan sistem zonasi di SD Kota Mataram, antara lain: (1) sekolah favorit masih terbatas, (2) pemerataan kualitas pendidikan yang masih timpang, dan (3) kurangnya sosialisasi dari pemerintah.
\end{abstract}

Kata kunci: Problematika, Penerimaan Peserta Didik Baru, Sistem Zonasi.

\section{PENDAHULUAN}

Sekolah merupakan usaha untuk menjaga kelangsungan hidup masyarakat. Dengan kata lain, sekolah dan masyarakat adalah dua hal penting yang tak terpisahkan. Dapat dikatakan bahwa sekolah merupakan bagian dari masyarakat. Oleh karena itu, bagaimana masyarakatnya, begitulah sekolah atau pendidikannya. ${ }^{1}$

Sekolah telah menjadi harapan khalayak umum. Melalui sekolah, masyarakat berharap bahwa cita-cita dan harapannya tercapai. Tercapainya cita-cita dan harapan tersebut telah dipercayakannya kepada pemerintah sehingga semua sekolah telah dianggap sama. Sekolah favorit atau sekolah unggulan sudah tidak ada lagi. Alhasil, Permendikbud Nomor 20 Tahun 2019 ditetapkan dan diberlakukan.

Dalam Permendikbud Nomor 20 Tahun 2019 tentang Perubahan atas Peraturan Menteri Pendidikan dan Kebudayaan Nomor 51 Tahun 2018 tentang Penerimaan Peserta Didik Baru pada Taman Kanak-Kanak, Sekolah Dasar, Sekolah Menengah Pertama, Sekolah Menengah Atas, dan Sekolah Menengah Kejuruan, diketahui bahwa Pasal 16 telah

${ }^{1}$ Siti Irene Astuti Dwiningrum, Sketsa Teori Persekolahan, (Yogyakarta: Program Pascasarjana Universitas Negeri Yogyakarta, 2014), h. 13. 
diatur tata cara pendaftaran penerimaan peserta didik baru (PPDB) melalui jalur zonasi, prestasi, dan perpindahan tugas orang tua/wali. ${ }^{2}$ Permendikbud tersebut diturunkan juga dalam Keputusan Kepala Dinas Kota Mataram Nomor 422.1/1520/Disdik.C3/VI/2019 tentang Petunjuk Teknis Pelaksanaan Penerimaan Peserta Didik Baru pada Taman KanakKanak dan Sekolah Dasar Kota Mataram Tahun Pelajaran 2019/2020. ${ }^{3}$ Konsekuensi Pasal 16 dan Keputusan Dinas Kota Mataram tersebut telah menimbulkan berbagai permasalahan. Banyak masyarakat merasakan konsekuensinya secara langsung bagi yang memiliki anak untuk mendaftar di sekolah baru. Para orang tua mengeluhkan sulitnya mendapatkan sekolah sesuai dengan keinginannya. Hal tersebut dikarenakan oleh pembatasan kuota peserta didik yang berasal dari daerah bukan sekitar sekolah tujuan. Alhasil, banyak peserta didik gagal menjadi peserta didik baru di sekolah unggulan karena tersisihkan oleh peserta didik yang secara jarak berdekatan dengan lokasi sekolah.

Sekolah unggulan telah menjadi harapan para orang tua untuk memilihkan anaknya sekolah. Hal tersebut secara tidak langsung menegaskan bahwa pemerintah harus mengakui keberadaan sekolah yang belum merata, baik dari segi fasilitas maupun kualitas gurunya. Kesempatan bersekolah atau pemerataan pendidikan merupakan kesempatan yang seluasluasnya kepada seluruh warga Negara untuk memperoleh pendidikan yang baik sehingga pendidikan itu menjadi sarana bagi pembangunan sumber daya manusia (SDM) dalam menunjang pembangunan. Seperti yang diketahui bahwa pemerataan pendidikan ini mencakup dua aspek penting, yaitu: (1) equality dan (2) equity. Equality berarti persamaan kesempatan untuk memperoleh pendidikan, sedangkan equity berarti keadilan dalam memperoleh kesempatan pendidikan yang sama di antara berbagai kelompok dalam masyarakat. ${ }^{4} \mathrm{Hal}$ ini berarti bahwa akses terhadap pendidikan yang merata bermakna semua penduduk usia sekolah telah memperoleh kesempatan pendidikan, sementara itu akses terhadap pendidikan telah adil jika antarkelompok bisa menikmati pendidikan secara sama.

2Kemendikbud, Permendikbud Nomor 20 Tabun 2019 tentang Perubahan atas Peraturan Menteri Pendidikan dan Kebudayaan Nomor 51 Tabun 2018 tentang Penerimaan Peserta Didik. Baru pada Taman Kanak-Kanak, Sekolah Dasar, Sekolah Menengah Pertama, Sekolah Menengah Atas, dan Sekolah Menengah Kejuruan (Jakarta: Kemendikbud, 2019), h. 5-6.

${ }^{3}$ Dinas Pendidikan Kota Mataram, Petunjuk Teknis Pelaksanaan Penerimaan Peserta Didik Baru pada Taman Kanak-Kanak dan Sekolah Dasar Kota Mataram Tabun Pelajaran 2019/2020, (Mataram: Disdik, 2019), h.1-10.

${ }^{4}$ Triwardono Argo Rekmo, Pemeratan Pendidikan, dalam https://argorekmomenoreh.wordpress.com/2013/12/28/ pemerataan-pendidikan/ diakses pada hari Selasa, 1 Juli 2019 Pukul 09.00 Wita. 
Oleh karena itu, sistem pendidikan modern di masyarakat seharusnya memenuhi dua fungsi mutlak yaitu: (1) membekali individu dengan pengetahuan yang memungkinkannya mengambil bagian dalam kehidupan sosial, ekonomi, dan politik; (2) memberikan akses pendidikan seluas-luasnya sebagai upaya pemerataan kualitas pendidikan. ${ }^{5}$

Namun, masalah pemerataan kualitas pendidikan ini belum pernah tuntas. Ada beberapa fenomena yang selalu dikaitkan dengan masalah pemeraataan kualitas pendidikan ini. Permasalahan tersebut di antaranya: (1) kurangnya fasilitas pendidikan yang tersedia; masih banyak warga negara khususnya anak usia sekolah yang tidak dapat ditampung dalam sistem atau lembaga pendidikan; (2) sarana dan prasarana antara di desa dan kota jauh berbeda; di desa-desa sarana dan prasarananya masih seadanya, sedangkan di kota-kota besar, sarana dan prasarananya sudah sangat maju; (3) kurangnya tenaga pengajar; di daerah bagian timur Indonesia bukan saja sarana dan prasarana yang kurang, melainkan juga kurangnya tenaga pengajar sehingga banyak sekolah masih membutuhkan guru-guru dari daerah lain; (4) masih banyak warga negara yang kurang mampu; walaupun tinggal di kotakota besar, warga Negara yang tidak mampu tidak dapat merasakan pendidikan sehingga masih di bawah umur sudah bekerja untuk membantu orang tuanya menjadi pengamen, pemulung, pengemis, dan sebagainya untuk mempertahankan hidupnya. ${ }^{6}$

Hal itulah yang menjadi alasan mendasar sehingga permasalahan tersebut masih timpang antara sekolah yang satu dengan sekolah yang lainnya. Begitu juga yang terjadi di Kota Mataram. Ada beberapa sekolah yang dijadikan pilihan favorit bagi orang tua. Sekolah-sekolah tersebut antara lain: (1) SD Negeri 2 Cakranegara, (2) SD Negeri 5 Mataram, dan (3) SD Negeri 1 Ampenan. Ketiga sekolah tersebut telah menjadi incaran para orang tua. Namun, para orang tua harus berhadapan dengan Permendikbud Nomor 20 Tahun 2019 dan Keputusan Kepala Dinas Pendidikan Kota Mataram terkait sistem zonasi. Pasalnya, banyak peserta didik yang berada di sekitaran sekolah favorit tersebut sehingga peluang untuk masuk sangat terbatas. Terbatasnya peluang tersebut telah menimbulkan berbagai problematika bagi orang tua, bahkan bagi pihak sekolah juga. Oleh

${ }^{5}$ Coleman, J. (1968). The Concept of Equality of Educational Opportunity. Harvard Educational Review, 38(1), 7-22. Retrieved from https:// files.eric.ed.gov/fulltext/ED015157.pdf

'Ibid

Copyright (C) el-Midad : Jurnal PGMI 2019 
karena itu, hal ini menjadi menarik dan penting untuk dikaji lebih mendalam sehingga dapat diungkap secara objektif permasalahannya.

\section{LANDASAN TEORI}

\section{A. Penerimaan Peserta Didik Baru (PPDB)}

\section{Pengertian Penerimaan Peserta Didik Baru (PPDB)}

Dalam Permendikbud Nomor 51 Tahun 2018 tentang Penerimaan Peserta Didik Baru pada Taman Kanak-Kanak, Sekolah Dasar, Sekolah Menengah Pertama, Sekolah Menengah Atas, dan Sekolah Menengah Kejuruan dijelaskan bahwa penerimaan peserta didik baru, yang selanjutnya disingkat (PPDB), adalah penerimaan peserta didik baru pada TK dan Sekolah. ${ }^{7}$ PPDB ini merupakan proses seleksi akademis calon siswa pada jenjang tertentu dengan aturan yang telah ditentukan. Tiap-tiap tingkatan sekolah memiliki cara tersendiri dalam PPDB, mulai dari TK, SD, SMP, SMA, dan SMK atau sederajat. PPDB ini dilaksanakan berdasarkan nondiskriminatif, objektif, transfaran, akuntabel, dan berkeadilan. Nondiskriminatif ini diperuntukkan bagi sekolah yang secara khusus melayani peserta didik dari kelompok gender atau agama tertentu. ${ }^{8}$

\section{Tujuan PPDB}

PPDB ini bertujuan untuk: (a) mendorong peningkatan akses layanan pendidikan; (b) digunakan sebagai pedoman bagi: (1) kepala daerah untuk membuat kebijakan teknis pelaksanaan PPDB dan menetapkan zonasi sesuai dengan kewenangannya; dan (2) kepala sekolah dalam melaksanakan PPDB. ${ }^{9}$ Selain itu, secara umum, tujuan PPDB ini adalah: (a) mengetahui kesadaran masyarakat, pada khususnya orang tua untuk menyekolahkan anakanaknya; (b) menjaring lulusan atau tamatan yang ditinggalkan oleh peserta didik yang naik kelas jenjang lebih tinggi; dan (c) mengetahui minat peserta didik untuk melanjutkan sekolah pada jenjang lebih tinggi. PPDB ini juga bertujuan agar tidak terjadi gap antara sekolah yang populer (favorit) dan sekolah yang non-favorit.

\footnotetext{
${ }^{7}$ Kemendikbud, Permendikbud Nomor 51 Tabun 2018 tentang Penerimaan Peserta Didik Baru pada Taman Kanak-Kanak, Sekolah Dasar, Sekolah Menengah Pertama, Sekolah Menengah Atas, dan Sekolah Menengah Kejuruan (Jakarta: Kemendikbud, 2018), h. 4.

${ }^{8}$ Ibid, h. 5-6.

${ }^{9}$ Ibid, h. 6. 


\section{Tata Cara dan Persyaratan PPDB}

Pelaksanaan PPDB dimulai dari tahap: (a) pengumuman pendaftaran penerimaan calon peserta didik baru pada sekolah yang bersangkutan yang dilakukan secara terbuka; (b) pendaftaran; (c) seleksi sesuai dengan jalur pendaftaran; (d) pengumuman penetapan peserta didik baru; dan (e) daftar ulang. Selanjutnya, untuk persyaratan PPDB kelas 1 (satu) SD adalah: (a) berusia 7 (tujuh) tahun atau paling rendah 6 (enam) tahun pada tanggal 1 Juli tahun berjalan; (b) sekolah wajib menerima peserta didik yang berusia 7 (tujuh) tahun; dan (c) pengecualian syarat usia paling rendah 6 (enam) tahun yaitu paling rendah 5 (lima) tahun 6 (enam) bulan pada tanggal 1 Juli tahun berjalan yang diperuntukkan bagi calon peserta didik yang memiliki potensi kecerdasan dan/atau bakat istimewa dan kesiapan psikis yang dibuktikan dengan rekomendasi tertulis dari psikolog profesional. ${ }^{10}$

\section{B. Sistem Zonasi}

\section{Pengertian Sistem Zonasi}

Sistem Zonasi adalah penataan reformasi dalam pembagian wilayah sekolah. ${ }^{11}$ Secara keseluruhan, sistem zonasi yang berlaku saat ini merupakan landasan pokok penataan reformasi sekolah mulai dari Taman Kanak-kanak (TK), Sekolah Dasar (SD), Sekolah Menengah Pertama (SMP), Sekolah Menengah Atas (SMA), Sekolah Menengah Kejuruan (SMK) atau sederajat. Sistem Zonasi yang mengatur mengenai zona wilayah bagi calon peserta didik dimuat dalam Sistem PPDB yang baru melalui Permendikbud Nomor 14 Tahun 2018 tentang Sistem Zonasi. Prinsip sistem zonasi ini hampir sama dengan sistem bina lingkungan. Perbedaannya dengan sistem zonasi ini hanya pada jumlah kuota. PPDB dengan sistem zonasi ini jauh lebih banyak dibandingkan bina lingkungan yaitu mencapai $90 \%$.

\section{Ketentuan dalam Sistem Zonasi}

PPDB dengan sistem zonasi ini memiliki ketentuan. ${ }^{12}$ Ketentuannya antara lain: (a) sekolah yang diselenggarakan oleh pemerintah daerah wajib menerima calon peserta didik yang berdomisili pada radius zona terdekat dari sekolah paling sedikit sebesar 90\%

${ }^{10}$ Ibid, h. 6-9.

${ }^{11}$ Kemendikbud, Permendikbud Nomor 14 Tahun 2018 tentang Sistem Zonasi (Jakarta: Kemendikbud, 2018). 12 Ibid 
(sembilan puluh persen) dari total jumlah keseluruhan peserta didik yang diterima; (b) domisili calon peserta didik berdasarkan alamat pada kartu keluarga yang diterbitkan paling lambat 6 (enam) bulan sebelum pelaksanaan PPDB; (c) radius zona terdekat ditetapkan oleh pemerintah daerah sesuai dengan kondisi di daerah tersebut berdasarkan: (1) ketersediaan anak usia sekolah di daerah tersebut, dan (2) jumlah ketersediaan daya tampung dalam rombongan belajar pada masing-masing sekolah; (d) dalam menetapkan radius zona, pemerintah daerah melibatkan musyawarah/kelompok kerja kepala sekolah; (e) bagi sekolah yang berada provinsi/kabupaten/kota, di daerah ketentuan perbatasan persentase dan radius zona terdekat dapat diterapkan melalui kesepakatan secara tertulis antar pemerintah daerah yang saling berbatasan; (f) sekolah yang diselenggarakan oleh pemerintah daerah dapat menerima calon peserta didik melalui: (1) jalur prestasi yang berdomisili di luar radius zona terdekat dari sekolah paling banyak 5\% (lima persen) dari total jumlah keseluruhan peserta didik yang diterima; dan (2) jalur bagi calon peserta didik yang berdomisili di luar zona terdekat dari sekolah dengan alasan khusus meliputi perpindahan domisili orangtua/wali peserta didik atau terjadi bencana alam/sosial, banyak 5\% (lima persen) dari total paling jumlah keseluruhan peserta didik yang diterima.

\section{METODE PENELITIAN}

Penelitian ini merupakan penelitian kualitatif. ${ }^{13}$ Subjek penelitian ini adalah kepala sekolah, para guru, dan wali murid di 3 sekolah dasar di Kota Mataram yang dianggap refresentatif dengan penelitian ini, sedangkan objek penelitian ini diambil dengan cara memilah data-data yang sesuai dengan kebutuhan dalam penelitian ini, yaitu: dititikberatkan pada problematika PPDB dengan sistem zonasi di sekolah dasar Kota Mataram. Dalam penelitian ini, instrumen pengumpulan data yang utama (key instrument) adalah peneliti sendiri. Data dikumpulkan dengan wawancara mendalam, observasi, dan dokumentasi. ${ }^{14}$ Teknik analisis data yang digunakan adalah analisis interaktif, yang terdiri dari tiga alur kegiatan yang berjalan secara simultan, yaitu reduksi data, penyajian data dan penarikan 1992).

${ }^{13 B}$ Bogdan. R.. C. \& Biklen. S. K., Qualitative Research for Education (United States Syarcuse University,

${ }^{14}$ Kerlinger. Asas-Asas Penelitian Behaviour, Edisi 3, Cetakan 7 (Yogyakarta: Gadjah Mada University Press, 2006). 
kesimpulan. Keabsahan data dilakukan dengan cara memperpanjang waktu pengamatan yang terus menerus, dan menguji dengan trianggulasi. ${ }^{15}$

\section{HASIL PENELITIAN DAN PEMBAHASAN}

\section{Hasil Penelitian}

PPDB dengan sistem zonasi ini telah menyebabkan polemik di masyarakat Mataram. Sementara, PPDB dengan sistem zonasi ini dimaksudkan untuk pemerataan kualitas pendidikan. Berikut ini diuraikan problematika PPDB dengan sistem zonasi di SD Kota Mataram berdasarkan temuan di lapangan.

\section{Sekolah favorit masih terbatas}

Sekolah unggulan atau favorit yang diinginkan para orang tua tidak dapat dicapai karena berada di zona yang berbeda. Akibatnya, orang tua terpaksa menyekolahkan anaknya di zona terdekat dengannya yang mutunya kurang baik. Hal tersebut didasarkan pada pengalaman sebelumnya bahwa sekolah-sekolah favorit itu sudah diketahui banyak orang karena selalu dibanjiri pendaftar. Artinya, sekolah favorit ini diperebutkan oleh banyak orang tua agar anaknya bisa sekolah di sana. Bahkan, sekolah favorit ini diasumsikannya sebagai sekolah yang dapat memberikan pengalaman yang lebih jika dibandingkan dengan sekolah yang tidak favorit. Sebagaimana penjelasan beberapa calon wali murid berikut ini. ${ }^{16}$

"Saya kan tahu mana sekolah yang unggul. Selama ini, anak-anak saya, anak yang pertama dan kedua, saya sekolahkan di SD ini dan diterima. Tapi, sekarang gak bisa karena kuota sudah penuh."

Hal senada juga diungkapkan oleh calon wali murid berikut ini. ${ }^{17}$

"Ya. Saya kok tidak sependapat dengan pemerintah dengan sistem zonasi ini. Saya juga kaget dengan aturan seperti ini. Jujur, saya tidak tahu kalau penerimaan siswa baru seperti saat ini. Kalau seperti ini modelnya, saya tidak bisa dong sekolahkan anak saya

\footnotetext{
${ }^{15}$ Miles, M.B., \& Huberman, A.M., Analisis Data Kualitatif. (Terjemahan Tjetjep Rohendi Rohidi, Jakarta, Universitas Indonesia Press, 1992).

16 Kusmayadi, Wawancara, SDN 2 Mataram, 2 Juli 2019.

${ }^{17}$ Nurhasanah, Wawancara, SDN 2 Cakranegara, 2 Juli 2019.
} 
sesuai dengan pilihan saya. Soalnya, saya tahu mana sekolah yang cocok dan bagus buat anak saya."

Dari kedua pendapat calon wali murid di atas, dapat dipahami bahwa orang tua masih memilihkan sekolah untuk anak-anaknya. Para orang tua mengetahui kualitas sekolah yang satu dengan yang lain berdasarkan sudut pandangnya. Sepertinya para orang tua ini telah melakukan survei dan observasi ke seokolah-sekolah yang dianggapnya unggul. Sekolah yang unggul akan memberikan pengalaman yang baik kepada anak-anaknya.

Di SDN 5 Mataram dan SDN 1 Ampenan, diperoleh informasi bahwa dua SD tersebut telah menjadi SD yang favorit bagi para orang tua. Para orang tua di sekitar dua SD tersebut merasa senang dengan PPDB dengan sistem zonasi tersebut. Menurutnya, kedua SD tersebut merupakan zona 'emas' sehingga akan berdampak positif bagi anak-anaknya. Sebagaimana dijelaskan oleh calon wali murid berikut ini. ${ }^{18}$

"Penerapan sistem zonasi dalam PPDB tahun ini memberikan efek positif bagi kami yang tinggal di sekitar sekolah yang difavoritkan banyak masyarakat. Ya, kami senang dong. Sebelumnya, kami agak kesusahan masuk di sekolah ini karena memang siswanya selalu penuh jauh-jauh sebelumnya. Bisa dikatakan bahwa siswanya itu sudah ada atau sudah dipesan oleh para orang tua jauh-jauh hari sebelumnya. Kalau sekarang ya tidak bisa dong karena yang diutamakan adalah masyarakat sekitar yang dekat dengan sekolah ini."

Senada dengan pendapat di atas, berikut yang dijelaskan oleh calon wali murid lainnya. ${ }^{19}$

"Dulu, orang-orang tertentu yang bisa masuk ke sekolah favorit. Bisa dikatakan orang tuanya itu dari kalangan menengah ke atas. Ini kan tidak adil namanya. Kita juga ingin anak kami sekolah di dekat rumah. Apalagi, sekolah itu dikenal sebagai sekolah yang favorit. Jujur saja, tahun-tahun sebelumnya, kami ini kesannya seperti penonton saja karena ada sekolah dekat rumah, tapi sekolahnya agak jauh dari rumah karena alasan sudah penuh."

Berdasarkan kedua pendapat di atas, dapat dipahami bahwa PPDB dengan sistem zonasi juga memberikan respon positif dari para orang tua yang rumahnya dekat dari sekolah yang difavoritkan oleh banyak orang tua. Sekolah favorit menjadi daya tarik yang luar biasa bagi para orang tua yang ingin mendapatkan sekolah yang baik untuk anak-

${ }^{18}$ Herman, Wawancara, SDN 5 Mataram, 1 Juli 2019

${ }^{19}$ Rahmawati, Wawancara, SDN 1 Ampenan, 1 Juli 2019 
anaknya. Namun, dengan sistem zonasi ini, para orang tua juga harus siap ditolak ketika banyak anak di sekitar sekolah favorit tersebut mendaftarkan diri di sekolah tersebut.

Di pihak lain, kepala sekolah dan guru juga tidak dapat menjelaskan secara detail latar belakang PPDB dengan sistem zonasi ini. Kepala sekolah dan guru hanya melaksanakan Surat Edaran Menteri Pendidikan dan Kebudayaan berupa Permendikbud Nomor 20 Tahun 2019 dan Petunjuk Teknis dari Kepala Dinas Pendidikan Kota Mataram. Dalam Permendikbud dan Petunjuk Teknis tersebut, telah dijelaskan tata cara PPDB tahun 2019 sehingga harus dilaksanakan. Hal tersebut dijelaskan oleh kepala sekolah berikut ini. ${ }^{20}$

"Kami hanya menjalankan Surat Edaran berupa Permendikbud Nomor 20 Tahun 2019 dan Petunjuk Teknis Kepala Dinas Pendidikan Kota Mataram terkait penerimaan peserta didik baru melalui sistem zonasi ini. Kami tidak bisa menjelaskan secara detail latar belakangnya. Setahu kami, pemerintah sudah menganggap bahwa semua sekolah sama sehingga sekolah di mana saja sama. Kami sih tidak mau ribet. Siswa dari mana saja kita terima. Jika kuota sudah terpenuhi, ya kita tutup meskipun masih banyak siswa yang mau daftar di sekolah kami."

Hal senada juga dijelaskan oleh guru berikut ini. ${ }^{21}$

"Kalau kami sebagai guru ikut kepala sekolah. Intinya, penerimaan peserta didik baru saat ini mengacu pada Permendikbud Nomor 20 Tahun 2019 dan Petunjuk Teknis dari Kepala Dinas Pendidikan Kota Mataram itu."

Kedua penjelasan di atas menjelaskan bahwa Surat Edaran Menteri Pendidikan dan Kebudayaan berupa Permendikbud Nomor 20 Tahun 2019 dan Petunjuk Teknis dari Kepala Dinas Pendidikan Kota Mataram telah dijadikan sebagai acuan dalam PPDB dengan sistem zonasi ini. Karena telah ditetapkan dan diberlakukan, pihak sekolah melaksanakannya dengan ketentuan yang ada dalam Permendikbud dan Petunjuk Teknis tersebut. Pemerintah juga telah menganggap bahwa semua sekolah sama sehingga peserta didik mau sekolah di mana saja bisa. Artinya, antara sekolah yang satu dengan yang lain tidak ada bedanya dari segi fasilitas dan kualitas guru.

${ }^{20}$ Wawancara, Hj. Baiq Aini, SDN 5 Mataram, 2 Juli 2019.

${ }^{21}$ Wawancara, Nurhasanah, SDN 5 Mataram, 2 Juli 2019. 


\section{Pemerataan kualitas pendidikan yang masih timpang}

Pemerataan kualitas pendidikan yang dimaksudkan adalah pemerataan dalam memberikan akses pendidikan, yakni berupa sarana prasarana dan fasilitas sekolah, metode pembelajaran, kualitas dan distribusi guru. Ukuran pemerataan kualitas pendidikan yang dimaksud tersebut mencakup semua sekolah. Dengan kata lain, semua sekolah memiliki sarana prasarana dan fasilitas sekolah yang sama, kualitas dan distribusi guru yang sama juga. Namun, fakta temuan di lapangan berbeda. Bahkan, masyarakat sendiri mampu membedakan antara satu sekolah dengan sekolah yang lainnya ditinjau dari pemerataan kualitas pendidikan di atas.

Hal tersebut telah memicu polemik di masyarakat Kota Mataram. Masyarakat Kota Mataram masih menganggap bahwa pemerataan kualitas pendidikan belum merata atau masih timpang. Alhasil, PPDB dengan sistem zonasi belum dapat diterima. Pemerintah dinilai tidak adil karena masih terdapat ketimpangan sekolah yang satu dengan yang lain dilihat dari fasilitas dan kualitas guru. Sebagaimana dijelaskan oleh calon wali murid berikut ini. $^{22}$

"Coba saja diperhatikan SDN 5 Mataram ini. Dari penampilan saja sudah berbeda dengan SDN 25 Mataram misalnya. Sekolahnya sama-sama negeri juga kan. Dan samasama berada di kelurahan Dasan Agung. Tetapi, lingkungan dan fasilitasnya jauh berbeda."

Hal senada juga disampaikan oleh calon wali murid berikut ini. ${ }^{23}$

"Saya sudah masuk ke SDN 2 Cakranegara dan SDN 1 Ampenan. Secara tampilan tidak jauh berbeda. Banyak kesamaannya. Coba bandingkan dengan SDN 26 Cakranegara atau SDN 9 Ampenan. Jauh berbeda. Ini artinya pemerataan yang dimaksudkan oleh pemerintah masih jauh dari harapan. Dan saya maunya anak saya sekolah di SDN 2 Cakranegara. Selain dekat dari rumah, bagus juga. Meskipun ada sekolah juga di lebih dekat dari rumah saya."

Kedua penjelasan di atas menjelaskan bahwa terciptanya pemerataan kualitas pendidikan yang dimaksudkan oleh pemerintah masih jauh dari harapan meskipun dengan PPDB sistem zonasi ini pemerintah akan mewujudkannya. Pemerataan kualitas pendidikan ini, seperti harapan pemerintah tersebut, bisa juga dipetakan melalui PPDB sistem zonasi

\footnotetext{
22Rusdi, Wawancara, SDN 5 Mataram, 3 Juli 2019.

${ }^{23}$ Kurniawan, Wawancara, SDN 1 Ampenan, 3 Juli 2019.
} 
ini. Dengan kata lain, pemerintah akan mengupayakan secepat mungkin kebutuhankebutuhan sekolah seperti sekolah-sekolah yang banyak diminati oleh masyarakat. Sekolahsekolah yang diminati oleh masyarakat tersebut bukan tidak beralasan. Alasan utamanya, bisa jadi karena sekolah tersebut didukung oleh fasilitas dan kualitas guru yang ideal. Oleh karena itu, PPDB dengan sistem zonasi ini akan berjalan baik untuk beberapa tahun ke depan jika pemerataan kualitas pendidikan diwujudkan pada semua sekolah.

Kepala sekolah dan guru juga mengakui bahwa pemerataan kualitas pendidikan yang diharapkan oleh pemerintah dapat terwujud secepat mungkin dengan memenuhi kebutuhan sekolah. Secara pribadi, kepala sekolah juga masih melihat ketimpangan di beberapa sekolah. Padahal, status sekolahnya sama, yaitu sekolah negeri.

Untuk mewujudkan semua itu, dibutuhkan waktu dan dana yang besar. Dengan begitu, PPDB dengan sistem zonasi, terciptanya pemerataan kualitas pendidikan seperti harapan pemerintah akan terwujud. Artinya, PPDB dengan sistem zonasi ini tidak menimbulkan polemik lagi di masyarakat. Hal tersebut sebagaimana dijelaskan oleh kepala sekolah berikut ini. $^{24}$

"Pemerintah seharusnya mengecek dulu ke sekolah-sekolah. Apakah sekolah yang satu dengan yang lain dari segi fasilitas sudah sama. Kalau dengan PPDB sistem zonasi ini, diharapkan dapat mewujudkan pemerataan pendidikan bisa saja. Tetapi, itukan jadinya membutuhkan proses. Pemerintah pasti sudah tahu jawabannya. Ada sekolah yang PPDB-nya membludak dan ada malah tidak memenuhi kuota alias kurang. Nah, ini kan sudah jelas. Ketika ada sekolah yang kurang diminati, pasti disebabkan oleh fasilitas dan kualitas guru yang diharapkan oleh orang tua masih jauh dari harapannya. Maksud saya, orang tua itu kan pilih-pilih juga sekolah untuk anaknya berdasarkan itu tadi, fasilitas dan lain-lain itu."

Hal tersebut senada juga dijelaskan oleh guru berikut. ${ }^{25}$

"Masalah sekolah bagus dan tidak bagus, di Kota Mataram ini sudah terbaca oleh para orang tua. Para orang tua ini sudah tahu mau masukkan anaknya di sekolah yang mana. Mereka tidak salah juga. Ketika ada sistem zonasi seperti ini, ditambah lagi akan sama nantinya sekolah yang satu dengan yang lainnya, mereka belum bisa menerima. Artinya, PPDB dengan sistem zonasi untuk menciptakan pemerataan pendidikan dinilai tidak mungkin."

${ }^{24} \mathrm{Hj}$. Hadijah, Wawancara, SDN 2 Cakranegara, 2 Juli 2019.

${ }^{25}$ Lalu Ahmad Kurniawan, Wawancara, SDN 2 Cakranegara, 2 Juli 2019. 
Dari penjelasan di atas, dapat dipahami bahwa pemerataan kualitas pendidikan seharusnya telah merata sebelum PPDB dengan sistem zonasi ini. Alasan pemerintah dengan tujuan menciptakan pemerataan kualitas pendidikan melalui PPDB dengan sistem zonasi ini mendapatkan perhatian serius dari masyarakat, baik calon wali murid maupun dari para guru. Tidak heran, masyarakat masih menganggap bahwa masih ada sekolahsekolah yang difavoritkan dan tidak difavoritkan. Masih ada lagi sekolah yang satu ramai dengan pendaftar dan sekolah yang lain malah kurang diminati. Dengan kata lain, masyarakat sudah tahu mana sekolah yang bagus untuk anak-anaknya. Hal inilah yang harus dievaluasi oleh pemerintah sehingga PPDB dengan sistem zonasi ini sesuai dengan harapan pemerintah.

\section{Kurangnya sosialisasi dari pemerintah}

Aturan PPDB yang dilakukan oleh pemerintah pusat seharusnya melibatkan pemerintah daerah. Pelibatan pemerintah daerah akan membantu pemerintah pusat dalam menyusun aturan yang tepat. Penyusunan aturan yang tepat diharapkan tidak menimbulkan kesalahpahaman di masyarakat. Kondisinya, masyarakat masih menolak kebijakan PPDB sistem zonasi ini. Padahal, masyarakat dan sekolah sebagai sasaran pelaksana aturan tersebut harus mengetahui secara detail aturan dalam PPDB. Dengan begitu, PPDB dengan sistem zonasi perlu dilakukan dan dapat berjalan dengan baik. Namun, PPDB dengan sistem zonasi ini mendapatkan kritikan dari masyarakat.

Masyarakat menilai bahwa pemerintah pusat seharusnya lebih gencar mensosilaisasikan secara teknis jauh hari sebelumnya sehingga maksud dan tujuan pemerintah diketahui dengan baik. Sosialisasi PPDB ini harus dilakukan secara terstruktur, sistematis, dan masif agar masyarakat paham. Padahal, kebijakan sistem zonasi ini dilakukan untuk memberi pelayanan akses yang berkeadilan kepada masyarakat, pemerataan kualitas pada semua satuan pendidikan, dan mendorong masyarakat dalam penyelenggaraan pendidikan. Dengan demikian, tidak ada lagi kecenderungan terpusatnya orang tua mendaftarkan anaknya pada sekolah tertentu yang dianggapnya unggulan dan favorit. Apalagi, membandingkan fasilitas dan kualitas satuan pendidikan yang satu dengan yang lainnya. Dengan kata lain, semua sekolah harus unggul dan berkualitas. 
Di Kota Mataram, masyarakat belum mengetahui PPDB dengan sistem zonasi ini. Masyarakat baru mengetahui ketika PPDB telah dibuka sejak tanggal 1 Juli 2019. Banyak yang protes kebijakan pemerintah tersebut. Kebijakan tersebut dinilai belum waktunya untuk dilaksanakan. Pemerintah diminta untuk meningkatkan sarana dan prasarana sekolah antara sekolah yang satu dengan yang lain agar tidak jauh berbeda. Selain itu, distribusi dan kualitas guru juga harus merata. Sebagaimana dijelaskan oleh calon wali murid berikut ini. ${ }^{26}$

"Kami belum tahu kebijakan ini. Seharusnya kami diberitahu agar kami paham. Saya sudah niat mendaftarkan anak saya sekolah di SDN 2 ini dari tahun lalu. Kalau sudah seperti ini, ya gimana. Saya gak mau di sekolah lain. Meskipun di sekitar rumah saya banyak sekolah juga."

Hal serupa juga disampaikan oleh calon wali murid berikut. ${ }^{27}$

"Saya bukannya tidak menerima kebijakan pemerintah seperti ini. Tetapi, apakah sekolah-sekolah ini sudah setara semuanya dari segi fasilitas dan mutu gurunya. Jika sudah setara, saya akan mendafatarkan anak saya di dekat rumah saja. Kalau situasinya seperti sekarang, saya gak mau. Pemerintah juga tidak ada sosialisasi kepada kami. Saya tidak tahu juga jika sudah disosialisasikan. Tetapi, saya yakin bahwa bukan saya saja yang belum tahu, melainkan banyak."

Hal berbeda dijelaskan oleh calon wali murid berikut. ${ }^{28}$

"Saya sih, mau tahu atau tidak kebijakan sistem zonasi ini tidak masalah karena rumah saya kan dekat dengan sekolah SDN 5 Mataram ini. Siapa yang tidak tahu dengan SD ini. Kami yang berada di dekat SDN 5 Mataram ini menyambut positif kebijakan ini karena banyak anak kami yang jadinya bisa sekolah di SD ini. Sebelumnya, SD ini kan dikenal sekolah hebat karena anak-anak yang sekolah di sini kelas menengah ke atas. Kami rata-rata tidak bisa masuk karena alasan kuota sudah penuh."

Dari penjelasan di atas, dapat dipahami bahwa pemerintah pusat dan pemerintah daerah harus bersinergi dalam mensosialisasikan PPDB dengan sistem zonasi ini jauh hari sebelumnya. Hal itu dapat dilakukan melalui kegiatan sosialisasi Dinas Pendidikan dengan sekolah-sekolah, melalui rapat komite, pengumuman-pengumuman melalui media massa dan elektronik, atau bisa juga melalui pengumuman-pengumuman pengeras suara

\footnotetext{
${ }^{26}$ Ellya, Wawancara, SDN 2 Cakranegara, 3 Juli 2019.

27Taufik, Wawancara, SDN 1 Ampenan, 3 Juli 2019.

${ }^{28}$ Ruslan, Wawancara, SDN 5 Mataram, 3 Juli 2019.
} 
di masjid dengan bekerjasama dengan tokoh masyarakat, tokoh agama, dan tokoh pemuda. Dengan begitu, kebijakan PPDB dengan sistem zonasi ini tidak menimbulkan polemik di masyarakat.

\section{Pembahasan}

\section{Penerimaan Peserta Didik Baru (PPDB) dengan Sistem Zonasi di SD Kota Mataram}

Di Mataram, PPDB dengan sistem zonasi ini telah dilaksanakan dalam dua tahun terakhir. Untuk PPDB 2019, SD di Kota Mataram telah mengacu Pasal 16 Permendikbud Nomor 20 Tahun 2019. Dalam Pasal 16 tersebut, dijelaskan bahwa PPDB dilaksanakan melalui jalur zonasi, prestasi, dan perpindahan tugas orang tua/wali. Ketentuan lebih lanjut dijelaskan bahwa jalur zonasi ditentukan paling sedikit 80\% dari daya tampung sekolah. Jalur prestasi ditentukan paling banyak 15\% dari daya tampung sekolah. Jalur perpindahan tugas orang tua/wali paling banyak 5\% dari daya tampung sekolah. Ketika telah melakukan pendaftaran PPDB melalui jalur zonasi yang sesuai dengan domisili dalam zonasi yang telah ditetapkan, calon peserta didik dapat melakukan pendaftaran PPDB melalui jalur prestasi di luar zonasi domisilinya. ${ }^{29}$

Selain Permendikbud Nomor 20 Tahun 2019 di atas, PPDB di Kota Mataram didasarkan juga pada Keputusan Kepala Dinas Kota Mataram Nomor 422.1/1520/Disdik.C3/VI/2019 tentang Petunjuk Teknis Pelaksanaan Penerimaan Peserta Didik Baru pada Taman Kanak-Kanak dan Sekolah Dasar Kota Mataram Tahun Pelajaran 2019/2020.30 Petunjuk teknis tersebut merupakan turunan dari Permendikbud Nomor 20 Tahun 2019 yang disesuaikan dengan kondisi daerah masing-masing. Untuk di SD Kota Mataram, PPDB dilakukan dengan sistem zonasi dan perpindahan. Selanjutnya, dari dua jalur tersebut, 95 persen diperuntukkan untuk sistem zonasi dan 5 persen untuk perpindahan. Kemudian, untuk seleksi calon peserta didik baru kelas 1 dilaksanakan berdasarkan usia dan jarak tempat tinggal ke sekolah. Untuk usia, peserta didik berusia 7 tahun dan berusia sekurang-kurangnya 6 tahun juga dapat diterima. Jumlah peserta didik

\footnotetext{
${ }^{29}$ Kemendikbud, Permendikbud Nomor 20 Tahun 2019 tentang Perubahan atas Peraturan Menteri Pendidikan dan Kebudayaan Nomor 51 Tabun 2018 tentang Penerimaan Peserta Didik Baru pada Taman Kanak-Kanak, Sekolah Dasar, Sekolah Menengah Pertama, Sekolah Menengah Atas, dan Sekolah Menengah Kejuruan Jakarta: Kemendikbud, 2019), h. 5-6.

${ }^{30}$ Dinas Pendidikan Kota Mataram, Petunjuk Teknis Pelaksanaan Penerimaan Peserta Didik Baru pada Taman Kanak-Kanak dan Sekolah Dasar Kota Mataram Tahun Pelajaran 2019/2020, (Mataram: Disdik, 2019), h.1-10. 
pada SD dalam satu kelas berjumlah paling sedikit 20 peserta didik dan paling banyak 28 peserta didik. Penentuan jumlah rombongan belajar/kelas baru paling banyak 4 rombongan belajar.

Kebijakan PPDB dengan sistem zonasi ini diharapkan agar semua warga Kota Mataram mendapatkan pendidikan yang lokasinya dekat dengan rumah masing-masing. Tidak itu saja, peserta didik juga lebih menghemat waktu dan menghemat biaya transportasi karena dekat dengan rumahnya. Tujuan utamanya adalah semua warga Kota Mataram mendapatkan pendidikan yang sama atau merata. Namun, pemerataan kualitas pendidikan yang dimaksudkan jauh dari harapan karena masih saja para orang tua memaksakan kehendaknya agar anaknya sekolah di sekolah yang diinginkannya. Penelitian yang dilakukan oleh Badan Perlindungan Lingkungan Amerika Serikat pada tahun 2003 menekankan bahwa pentingnya kedekatan sekolah dan pilihan sekolah dalam mendorong siswa untuk berjalan kaki dan bersepeda ke sekolah pada siswa sekolah dasar. ${ }^{31}$ Penelitian tersebut menjelaskan bahwa orang tua lebih banyak menyekolahkan anaknya di sekolah yang dekat dengan rumahnya dibandingkan dengan sekolah yang jaraknya jauh dari rumahnya karena alasan pilihan sekolah yang diinginkannya.

Selain itu, ada juga para orang tua memaksakan kehendaknya dalam PPDB bukan tidak beralasan. Alasan pertama karena fasilitas sekolah. Fasilitas sekolah yang berada di pinggir kota dengan di tengah kota tidak sama atau jauh bedanya. Para orang tua meyakini bahwa tersedianya fasilitas yang baik dan lengkap akan menciptakan pembelajaran yang sukses. Seperti dijelaskan oleh Barnawi dan M. Arifin bahwa tersedianya alat-alat atau fasilitas belajar yang memadai secara kuantitatif, kualitatif, dan relevan dengan kebutuhan serta dapat dimanfaatkan secara optimal dapat mencapai tujuan pembelajaran dengan baik. ${ }^{32}$ Alasan kedua karena kualitas guru. Para guru di sekolah pinggiran kota masih banyak yang honorer, sedangkan di tengah kota banyak yang sudah pegawai negeri sipil (PNS). Hal tersebut telah menunjukkan pemerataan kualitas pendidikan yang sangat jauh dari harapan.

${ }^{31}$ Wilson, E. J., Marshall, J., Wilson, R., \& Krizek, K. J. (2010). By Foot, Bus or Car: Children's School Travel and School Choice Policy. Environment and Planning A, 42(9), 2168-2185. https:/ / doi.org/ 10.1068/a435

${ }^{32}$ Barnawi dan M. Arifin, Manajemen Sarana dan Prasarana Sekolah, (Yogyakarta: Ar-Ruzz Media, 2012), h. 48. 
Padahal, salah satu indikatornya adalah kualitas guru sama, baik di pinggir atau di tengah kota.

\section{Problematika Penerimaan Peserta Didik Baru (PPDB) dengan Sistem Zonasi di SD Kota Mataram}

\section{Sekolah favorit masih terbatas}

Salah satu tujuan dari PPDB dengan sistem zonasi ini adalah mendorong akses layanan pendidikan. Dengan kata lain, dengan sistem zonasi ini tidak akan terjadi gap antara sekolah yang favorit dengan sekolah yang non-favorit. Namun, fakta di lapangan berbeda. Sekolah unggulan atau favorit masih ada dan menjadi rebutan para orang tua.

Kemauan para orang tua untuk mendaftarkan anaknya di sekolah yang favorit terbentur oleh Permendikbud Nomor 20 Tahun 2019. Permendikbud tersebut secara jelas mengatur tata cara PPDB. Salah satunya adalah dengan sistem zonasi. Dengan sistem zonasi tersebut, para orang tua tidak dapat mendaftarkan lagi anaknya di zona yang jauh dari rumahnya. Akibatnya, para orang tua terpaksa menyekolahkan anaknya di zona terdekat dengannya yang mutunya dianggap kurang baik. Para orang tua menganggap bahwa masih ada sekolah yang bagus, tetapi terbatas. Terbatasnya sekolah favorit tersebut, secara tidak langsung memberikan masukan kepada pemerintah bahwa peningkatan akses layanan pendidikan seharusnya terpenuhi terlebih dahulu sebelum PPDB dengan sistem zonasi ini ditetapkan dan diberlakukan. Alhasil, para orang tua memilihkan anaknya sekolah yang sudah terbukti kualitasnya. Sebagaimana dijelaskan oleh Siti Irene Astuti Dwiningrum bahwa good school menekankan pada mutu. Perbedaan mutu antar sekolah menyebabkan dampak pada prestasi siswa. ${ }^{33}$ Azizah Arifinna Safarah dan Udik Budi Wibowo juga menjelaskan bahwa sitem zonasi ini telah meratakan ketimpangan kualitas pendidikan. Label sekolah favorit tidak boleh lagi. ${ }^{34}$

\section{Pemerataan kualitas pendidikan yang masih timpang}

Kebijakan PPDB dengan sistem zonasi ini dipicu oleh argumentasi pemerintah yang menyatakan bahwa tujuannya adalah untuk menciptakan pemerataan kualitas pendidikan. ${ }^{35}$

${ }^{33}$ Siti Irene Astuti Dwiningrum, Sketsa Teori Persekolahan ..., h. 33.

${ }^{34}$ Azizah Arifinna Safarah dan Udik Budi Wibowo, Program Zonasi di Sekolah Dasar sebagai Upaya Pemerataan Kualitas Pendidikan di Indonesia, Jurnal Lentera Pendidikan Vol. 21 No. 2 Desember 2018: 2062013, DOI: $10.24252 / \mathrm{lp} .2018 v 21 \mathrm{n} 2 \mathrm{i} 6$

${ }^{35}$ Ibid 
Pemerataan kualitas pendidikan yang dimaksudkan oleh pemerintah masih jauh dari harapan meskipun dengan PPDB sistem zonasi ini pemerintah akan mewujudkannya. Pemerataan kualitas pendidikan ini, seperti harapan pemerintah tersebut, bisa juga dipetakan melalui PPDB sistem zonasi ini. Dengan kata lain, pemerintah akan mengupayakan secepat mungkin kebutuhan-kebutuhan sekolah seperti sekolah-sekolah yang banyak diminati oleh masyarakat. Sekolah-sekolah yang diminati oleh masyarakat tersebut bukan tidak beralasan. Alasan utamanya, bisa jadi karena sekolah tersebut didukung oleh fasilitas dan kualitas guru yang ideal. Oleh karena itu, PPDB dengan sistem zonasi ini akan berjalan baik untuk beberapa tahun ke depan jika pemerataan kualitas pendidikan diwujudkan pada semua sekolah.

Untuk mewujudkan semua itu, dibutuhkan waktu dan dana yang besar. Dengan begitu, PPDB dengan sistem zonasi, terciptanya pemerataan kualitas pendidikan seperti harapan pemerintah akan terwujud. Artinya, PPDB dengan sistem zonasi ini tidak menimbulkan polemik lagi di masyarakat. Hal inilah yang harus dievaluasi oleh pemerintah secara terusmenerus sehingga PPDB dengan sistem zonasi ini sesuai dengan harapan pemerintah.

\section{Kurangnya sosialisasi dari pemerintah}

Setiap kebijakan yang ditetapkan dan diberlakukan oleh pemerintah seharusnya disosialisasikan secara terstruktur, sistematis, dan masif agar masyarakat paham dan tidak terjadi polemik. Kebijakan pemerintah terhadap PPDB dengan sistem zonasi ini mendapatkan direspon positif dan negatif dari masyarakat. Masyarakat yang tinggalnya di sekitar sekolah yang kualitasnya bagus akan merasa senang dengan PPDB dengan sistem zonasi ini, sedangkan yang tinggalnya jauh dari sekolah yang bagus tersebut merasa adil. Oleh karena itu, sosialisasi menjadi faktor penentu juga dalam menentapkan dan memberlakukan suatu kebijakan.

Kebijakan PPDB yang ditetapkan dan diberlakukan oleh pemerintah pusat seharusnya melibatkan pemerintah daerah. Pelibatan pemerintah daerah akan membantu pemerintah pusat dalam menyusun aturan yang tepat. Penyusunan aturan yang tepat diharapkan tidak menimbulkan kesalahpahaman di masyarakat. Untuk itu, pemerintah pusat dan pemerintah daerah harus bersinergi dalam mensosialisasikan PPDB dengan sistem zonasi ini jauh hari 
sebelumnya. Hal tersebut dapat dilakukan melalui kegiatan sosialisasi Dinas Pendidikan dengan sekolah-sekolah, melalui rapat komite, pengumuman-pengumuman melalui media massa dan elektronik, atau bisa juga melalui pengumuman-pengumuman pengeras suara di masjid dengan bekerjasama dengan tokoh masyarakat, tokoh agama, dan tokoh pemuda. Dengan begitu, kebijakan PPDB dengan sistem zonasi ini berjalan dengan baik.

\section{SIMPULAN DAN SARAN}

\section{Simpulan}

PPDB dengan sistem zonasi di SD Kota Mataram masih mengalami polemik di masyarakat. Polemik tersebut antara lain dikarenakan oleh masih terbatasnya sekolah favorit, pemerataan kualitas pendidikan yang masih timpang, dan kurangnya sosialisasi dari pemerintah. Pertama, keberadaan sekolah favorit tidak dapat dipandang sebelah mata meskipun tujuan utama dari PPDB dengan sistem zonasi ini adalah untuk menghilangkan label sekolah favorit. Asumsi pemerintah yang menganggap semua sekolah adalah setara belum diterima oleh para calon wali murid sehingga PPDB dengan sistem zonasi tersebut diabaikan dan memaksakan kehendaknya untuk mendaftarkan anak-anaknya di sekolahsekolah yang dianggapnya bermutu. Kedua, pemerataan kualitas pendidikan yang dianggap setara ternyata masih timpang antara satu sekolah dengan sekolah yang lain. Ketiga, kurangnya sosialisasi dari pemerintah ini diketahui dari ketidaktahuan dan ketidakpahaman para calon wali murid dalam PPDB dengan sistem zonasi. Untuk itu, pemerintah pusat dan pemerintah daerah bersinergi bersama dalam mensosialisasikannya kepada masyarakat. Sosialisasi tersebut dapat dilakukan dengan cara mengadakan kegiatan sosialisasi dari Dinas Pendidikan dengan sekolah-sekolah, melalui rapat komite, pengumuman-pengumuman melalui media massa dan elektronik, atau bisa juga melalui pengumuman-pengumuman pengeras suara di masjid dengan bekerjasama dengan tokoh masyarakat, tokoh agama, dan tokoh pemuda. Dengan begitu, kebijakan PPDB dengan sistem zonasi ini tidak menimbulkan permasalahan lagi di masyarakat. 


\section{Saran}

Kebijakan pemerintah terhadap PPDB dengan sistem zonasi ini diharapkan, antara lain: (1) pemerintah harus memenuhi fasilitas dan kualitas guru di semua sekolah terlebih dahulu; (2) pemerintah sesegera mungkin mengupayakan kebutuhan-kebutuhan sekolah agar pemerataan kualitas pendidikan merata; dan (3) pemerintah harus mensosialisasikannya secara intensif agar PPDB dengan sistem zonasi ini berjalan dengan baik ke depannya dan terwujudnya pemerataan kualitas pendidikan pada semua sekolah.

\section{DAFTAR PUSTAKA}

Azizah Arifinna Safarah dan Udik Budi Wibowo, Program Zonasi di Sekolah Dasar sebagai Upaya Pemerataan Kualitas Pendidikan di Indonesia, Jurnal Lentera Pendidikan Vol. 21 No. 2 Desember 2018: 206-2013, DOI: 10.24252/lp.2018v21n2i6

Barnawi dan M. Arifin. Manajemen Sarana dan Prasarana Sekolah. Yogyakarta: Ar-Ruzz Media, 2012.

Bogdan. R.. C. \& Biklen. S. K. Qualitative Research for Education. United States Syarcuse University, 1992.

Coleman, J. (1968). The Concept of Equality of Educational Opportunity. Harvard Educational Review, 38(1), 7-22. Retrieved from https://files.eric.ed.gov/fulltext/ED015157.pdf

Dinas Pendidikan Kota Mataram. Petunjuk Teknis Pelaksanaan Penerimaan Peserta Didik Baru pada Taman Kanak-Kanak dan Sekolah Dasar Kota Mataram Tabun Pelajaran 2019/2020. Mataram: Disdik, 2019.

Kemendikbud. Permendikbud Nomor 20 Tabun 2019 tentang Perubahan atas Peraturan Menteri Pendidikan dan Kebudayaan Nomor 51 Tahun 2018 tentang Penerimaan Peserta Didik Baru pada Taman Kanak-Kanak, Sekolah Dasar, Sekolah Menengah Pertama, Sekolah Menengah Atas, dan Sekolah Menengah Kejuruan. Jakarta: Kemendikbud, 2019. Permendikbud Nomor 51 Tabun 2018 tentang Penerimaan Peserta Didik Baru pada Taman Kanak-Kanak, Sekolah Dasar, Sekolah Menengah Pertama, Sekolah Menengah Atas, dan Sekolah Menengah Kejuruan. Jakarta: Kemendikbud, 2018. 
- Permendikbud Nomor 14 Tahun 2018 tentang Sistem Zonasi. Jakarta: Kemendikbud, 2018.

Kerlinger. Asas-Asas Penelitian Behaviour, Edisi 3, Cetakan 7. Yogyakarta: Gadjah Mada University Press, 2006.

Miles, M.B., \& Huberman, A.M. Analisis Data Kualitatif. Terjemahan Tjetjep Rohendi Rohidi, Jakarta, Universitas Indonesia Press, 1992.

Siti Irene Astuti Dwiningrum. Sketsa Teori Persekolahan. Yogyakarta: Program Pascasarjana Universitas Negeri Yogyakarta, 2014.

Triwardono Argo Rekmo, Pemerataan Pendidikan, dalam https://argorekmo menoreh.wordpress.com/2013/12/28/pemerataan-pendidikan/ diakses pada hari Selasa, 12 Juni 2019 Pukul 09.00 Wita.

Wilson, E. J., Marshall, J., Wilson, R., \& Krizek, K. J. (2010). By Foot, Bus or Car: Children's School Travel and School Choice Policy. Environment and Planning A, 42(9), 2168-2185. https://doi.org/10.1068/a435 